ISSN 2356-3397 (Print) | ISSN 2597-4505 (Online)

\title{
PERSEPSI SISWA KELAS VIII TERHADAP PEMBELAJARAN AKTIVITAS AKUATIK
}

\author{
Yusuf Pemdiansyah ${ }^{1}$, Ruslan Abdul Gani ${ }^{2}$, Nana Suryana Nasution ${ }^{3}$ \\ 1,2,3 Pendidikan Jasmani Kesehatan dan Rekreasi \\ Fakultas Keguruan Dan IImu Pendidikan \\ Universitas Singaperbangsa Karawang, Indonesia \\ e-mail:pepenyusuf20@gmail.com, ruslan.abdulgani@staff.unsika.ac.id, \\ nana.suryananasution@fkip.unsika.ac.id
}

\begin{abstract}
Abstrak
Penelitian ini bertujuan untuk mengetahui persepsi siswa kelas VIII terhadap pembelajaran aktivitas akuatik di SMP Islam Al-falah Bantargebang. Penelitian ini merupakan penelitian kuantitatif dengan pendekatan deskriptif. Populasi yang digunakan adalah siswa kelas VIII. Sampel yang digunakan dalam penelitian ini sebanyak 90 siswa dengan teknik pengambilan sampel yaitu Total Sampling. Metode penelitian yang digunakan dalam penelitian ini yaitu metode survei. Teknik pengambilan data dalam penelitian ini menggunakan angket. Hasil penelitian menunjukan bahwa persepsi siswa kelas VIII terhadap pembelajaran aktivitas akuatik di SMP Islam Al-falah Bantargebang pada kategori sangat baik dengan persentase $17 \%$ atau 15 siswa, kategori baik dengan persentase $21 \%$ atau 19 siswa, kategori cukup baik $50 \%$ atau 45 siswa, kategori kurang baik dengan persentase $12 \%$ atau 11 siswa. Dapat disimpulkan bahwa persepsi siswa kelas VIII terhadap pembelajaran aktivitas akuatik di SMP Islam Al-falah Bantargebang berada pada kategori cukup baik dilihat berdasarkan pada tabel kategori variable.
\end{abstract}

Kata kunci : persepsi siswa, pembelajaran, aktivitas akuatik

\begin{abstract}
This study aims to determine the perceptions of grade VIII students towards learning aquatic activities at Islamic Junior High School Al-Falah Bantargebang. This research is a quantitative research with a descriptive approach. The population used was grade VIII students. The sample used in this study were 90 students with the sampling technique, namely Total Sampling. The research method used in this research is the survey method. The data collection technique in this study used a questionnaire. The results showed that the perceptions of grade VIII students towards learning aquatic activities at the Islamic Junior High School Al-falah Bantargebang were in the very good category with a percentage of $17 \%$ or 15 students, the good category with a percentage of $21 \%$ or 19 students, the good category was $50 \%$ or 45 students, poor category with a percentage of $12 \%$ or 11 students. It can be concluded that the students' perceptions of grade VIII towards learning aquatic activities at Islamic Junior High School Al-Falah Bantargebang are in a fairly good category as seen based on the variable category table.
\end{abstract}

Keywords: student perception, learning , aquatic activities

\section{PENDAHULUAN}

Pada dasarnya pendidikan merupakan suatu hak bagi manusia, karena pendidikan sangat berperan penting dalam memajukan suatu bangsa pada saat ini. Pendidikan merupakan suatu sumber daya manusia yang memiliki nilai strategis bagi keberlangsungan hidup manusia di dunia dalam jangka panjang (Jayamala, A. K., R Latha, B. L. Preethi, Nirmala N, K Tamilselvan, 2018:94). Saat ini, dalam ranah pendidikan modern memiliki aspek yang dikembangkan yaitu aspek kognitif merupakan aspek yang berkaitan dengan nalar atau proses berpikir, serta aspek afektif merupkan segala sesuatu yang berkaitan dengan emosional seperti penghargaan, nilai, perasaan, 
semangat, dan minat, dan yang terkahir aspek psikomotor merupakan suatu tahap menengah dalam mempelajari suatu keterampilan yang kompleks. (Khodari, 2017:124). Maka dari itu, dalam proses pembelajaran bahwa siswa yang mulanya tidak tahu akan menjadi tahu, dan awalnya tidak bisa menjadi bisa dengan seperti itu akan tercipta dalam suatu pendidikan (Sofiarini, 2016:69). Jadi dapat di simpulkan bahwa suatu pedidikan merupakan sumber daya manusia untuk mengembangkan aspek kognitif, afektif, dan psikomotor dalam proses pembelajaran di suatu pendidikan.

Salah satu pembelajaran yang dilaksanakan di satuan Pendidikan adalah Pendidikan Jasmani, Olahraga dan Kesehatan (PJOK). Pendidikan jasmani adalah bagian dari keseluruhan proses pendidikan dan mementingkan perubahan serta suatu hasil (Gani et al., 2019:20). Pendidikan jasmani merupakan suatu media untuk menunjang dalam perkembangan keterampilan motorik, fisik, pengetahuan, penalaran pengahayatan nilai, dan pembahasan pola hidup sehat (Wibowo \& Gani, 2018:46).Dapat disimpulkan bahwa pendidikan jasmani merupakan media atau salah satu alat yang penting sebagai penunjang dalam perkembangan aspek kognitif, afektif, dan psikomotor. Maka dari itu setiap pengajar dapat membantu siswa dalam mata pelajaran pendidikan jasmani dengan memberikan persepsi terhadap pembalajaran pendidikan jasmani. Oleh karena itu sebagai seorang pengajar kita harus tahu terlebih dahulu persepsi siswa agar dapat mengetahui siswa nya lebih baik lagi dalam pembelajaran pendidikan jasmani. Persepsi merupakan suatu pesan atau pendapat yang ingin di sampaikan oleh seseorang berupa peristiwa berdasarkan pengalamannya dengan tujuan tertentu (Septiana, 2016:167). Suatu persepsi yang kurang meluas dan keliru pada pendidikan jasmani akan mengakibatkan nilai luhur dan tujuan pendidikan yang terkandung di dalamnya tidak akan pernah tercapai dalam suatu proses pembelajaran (Febrianto \& Priambodo, 2019:24). Setiap orang mempunyai persepsi yang berbeda beda, hal ini dipengaruhi oleh pengetahuan seseorang, kebutuhan seseorang, kesenangan seseorang, dan pola hidup seseorang (Satria, 2017:2). Persepsi setiap individu dapat sangat berbeda walaupun yang diamati benar - benar sama. Dikarenakan setiap individu yang akan menghayati atau mengamati suatu objek sesuai dengan berbagai faktor yang diterimanya serta berkaitan dengan individu yaitu, lingkungan fisik dan sosial, struktural jasmani, kebutuhan dan tujuan hidup, pengalaman masa lampau. Menurut pendapat beberapa ahli tersebut, dapat disimpulkan bahwa presepsi adalah suatu tanggapan atau sebuah respon seseorang terhadap suatu objek melalui alat inderanya sesuai dengan situasi dan kondisi yang dialami 13 oleh individu. Dengan adanya presepsi ini maka akan menimbulkan sebuah sikap dan tindakan sesuai dengan situasi yang sedang dialami, serta kemudian akan menimbulkan tanggapan yang berbeda-beda pada setiap individu. Pembelajaran merupakan suatu proses interaksi atara peserta didik dengan pendidik untuk mencapai tujuan pembelajaran. Kemudian dalam konsep pembeajaran merupakan suatu usaha untuk mempermudah peserta didik dalam pelaksanaan pembelajaran (Mashud, 2014:2). Pembelajaran yaitu suatu usaha untuk penguasaan materi ilmu pengetahuan yang menunjukan terbentuknya suatu kepribadian yang utuh (Hendri,Gus.Aziz, 2020:175). Oleh karena itu dapat di simpulkan bahwa pada dasarnya pembelajaran juga sebagai proses memberikan bimbingan atau bantuan kepada siswa dalam melaksanakan proses belajar. Dalam pelaksanaan pembelajaran salah satunya mata pembelajaran pendidikan jasmani yang mempelajari pelajaran aktivitas akuatik.

Aktivitas akuatik adalah aktivitas yang bentuk kegiatan nya di air yang bisa dilakukan di kolam renang, pantai, sungai, danau, dan laut. Pembelajaran aktivitas akuatik adalah mata pelajaran wajib di sekolah dikarenakan sangat bermanfaat bagi siswa, dan sesuai dengan tujuan dari pembelajaran pendidikan jasmani (Gani, Ruslan abdul, A. Sukur, 2019:108). Suatu pembelajaran aktivitas akuatik mencangkup permainan air, keselamatan air, keterampilan gerak di air, dan berenang (Sukmawati \& Hartoto, 2015:367). Dapat di simpulkan bahwa pembelajaran aktivitas akuatik 
merupakan pembelajaran yang aktivitasnya dilakukan di air, pembelajaran aktivitas akuatik sangat tepat diberikan kepada siswa guna meningkatkan tujuan dari pembelajaran pendidikan jasmani, dan siswa bisa menyelamatkan dirinya sendiri apabila terjadi sesuatu di air. Selain dari kondisi siswa persepsi siswa merupakan suatu hal yang sangat penting untuk membantu guru dalam terciptanya dari tujuan pembelajaran. Siswa yang malas dalam kegiatan pembelajaran aktivitas akuatik agar tidak memberikan dampak negatif terhadap siswa yang lainnya justru siswa yang mempunyai persepsi yang positif terhadap pembelajaran aktivitas akuatik akan memberikan dampak yang positif terhadap siswa yang malas mengikuti pembelajaran aktivitas akuatik.

Berdasarkan pengamatan yang dilakukan oleh peneliti dengan melakukan wawancara kepada siswa kelas VIII di SMP Islam Al-falah Bantargebang peneliti menemukan ada beberapa masalah yaitu ada siswa yang masih takut tenggelam karena masih terauma pernah tenggelam, siswa takut karena panas, dan siswa mngeluh karena jarak kolam renang yang lumayan jauh. Tetapi ada siswa juga yang senang terhadap pembelajaran aktivitas akuatik, siswa memiliki banyak teman, dan membuat badan siswa menjadi lebih sehat dan bugar. Dari observasi tersebut peneliti tertarik ingin meneliti bagaimana persepsi siswa kelas VIII terhadap pembelajaran aktivitas akuatik di SMP Islam Al-falah Bantargebang Kota Bekasi. Penelitian ini telah di lakukan oleh Septyan Wahyu Adhitama (2016) dengan judul Persepsi Siswa Kelas VIII Terhadap Pembelajaran Aktivitas Air di SMP Negeri 2 Kelaten. Dengan data dari penelitiannya adalah klasifikasi sangat baik pada persentase $(65,7 \%)$, klasifikasi baik pada persentase $(34,3 \%)$, klasifikasi cukup baik pada persentase $(11,4 \%)$, dan klasifikasi kurang baik pada persentase $(0 \%)$. Maka hasil dari penelitian tersebut yaitu dengan klasifikasi sangat baik dengan persentase $(65,7 \%)$. Selanjutnya penelitian yang di lakukan oleh Yudi Ruspiandi tahun 2016 dengan judul Persepsi siswa SMA Negeri 1 Parigi Terhadap Pembelajaran Renang. Dengan data dari penelitian nya adalah klasifikasi sangat baik pada persentase $(72,22 \%)$, klasifikasi baik pada persentase $(25,00 \%)$, klasifikasi cukup baik pada persentase $(20,78 \%)$, dan klasifikasi kurang baik pada persentase $(0 \%)$. Maka data dari hasil penelitian tersebut dengan klasifikasi sangat baik dengan persentase $(72,22 \%)$.

Adapun penelitian yang telah di lakukan oleh Sandhi \& Hartanto (2018) dengan judul Persepsi Siswa Kelas VIII Terhadap Hasil Belajar Siswa pada Pembelajaran Aktivitas Aquatik di SMP Negeri 1 Lemahabang. Dengan data dari penelitiannya adalah klasifikasi sangat baik pada persentase $(79,2 \%)$, klasifikasi baik pada persentase $(33,6 \%)$, klasifikasi kurang baik pada persentase $(52,8 \%)$, dan klasifikasi tidak baik pada persentase $(5,94 \%)$. Maka hasil dari penelitian tersebut yaitu dengan klasifikasi kurang baik dengan persentase $(52,8 \%)$. Ini menunjukan bahwa hasil belajar siswa terhadap pembelajaran aktivitas akuatik masih dibilang kurang dan perlu ditingkatkan. Penelitian ini sama-sama mengukur tingkat persepsi siswa terhadap pembelajaran aktivitas akuatik namun sampel berbeda dan hasil akhir pun berbeda. Peneliti mengukur tingkat persepsi siswa kelas VIII di SMP Islam Al-falah Bantargebang penelitian ini menarik karena belum pernah di lakukan di SMP Islam Al-falah Bantargebang Kota Bekasi, dan keterbaharuan penelitian ini adalah letak geografis sekolahan yang di perkotaan.

\section{METODE}

Jenis penelitian ini merupakan deskriptif kuantitatif. Penelitian kuantitatif merupakan penelitian yang menggunakan dengan angka-angka dan analisis menggunakan data statistik. Metode yang digunakan dalam penelitian ini adalah metode survei. Metode survei merupakan salah satu pendekatan penelitian yang pada umumnya digunakan untuk pengumpulan data seluas-luasnya (Arikunto, 2014:16). Penelitian ini dilakukan di SMP Islam Al-Falah Bantargebang Kota Bekasi Waktu pengambilan data 
penelitian dilakukan selama 2 minggu. Populasi dalam penelitian ini adalah keseluruhan siswa kelas VIII di SMP Islam Al-falah Bantargebang yang berjumlah 90 siswa.Teknik pengambilan sampel dalam penelitian ini adalah total sampling. Total sampling merupakan jika sampel kurang dari 100 maka diambil adalah semuanya (Sugiyono, 2018:134). Kemudian teknik analisis data dalam penelitian ini menggunakan teknik analisis data kuantitatif dengan pendekatan deskriptif perhitungan dalam penelitian ini menggunakan Microsoft Excel tahun 2013. Sedangkan teknik pengumpulan data yang digunakan dalam penelitian menggunakan instrument yang berupa angket.

Uji coba validitas instrumen penelitian dilakukan pada siswa kelas VIII di SMP Islam Harapan Ummat Kabupaten Karawang dengan instrumen penelitian menggunakan angket. Hasil validitas diujicobakan kepada 40 reponden dan menggunakan taraf signifikan $0,05 \mathrm{r}$ tabel $=0.632$. Hasil perhitungan instrument penelitian dinyatakan valid sebab $r$ hitung $>r$ tabel. Sedangkan hasil uji reliabilitas diperoleh harga $r_{11}=0.836>r_{\text {tabel }}=0.632$ dengan demikian menunjukan angket yang diujicobakan reliabel dan dapat digunakan untuk pengumpulan data penelitian. Pengujian validitas dan reliabilitas instrument dilakukan dengan bantuan aplikasi Microsoft Excel tahun 2013.

Teknik analisis data penelitian ini adalah analisis statistik deskriptif dimana menggunakan metode penelitian angket. Kemudian untuk membuat kategori pengelompokan, harus mengetahui besarnya nilai rata-rata hitung dan besaran standar deviasi dari skor yang diperoleh.

Tabel 1. Konversi Skor Menjadi Kategori Kecenderungan Variabel

\begin{tabular}{cc}
\hline Interval & Kategori \\
\hline$X \geq M+1 . S D$ & Sangat Baik \\
$M \leq X<M+1 . S D$ & Baik \\
$M-1 . S D \leq X<M$ & Cukup Baik \\
$M-1 . S D>X$ & Kurang Baik \\
\hline
\end{tabular}

\section{HASIL DAN PEMBAHASAN \\ Hasil}

Untuk mengetahui Persepsi Siswa Kelas VIII Terhadap Pembelajaran Aktivitas Akuatik di SMP Islam Alfalah Bantargebang diukur dengan angket yang berjumlah 31 butir pernyataan, disebar melalui googleform kepada para siswa melalui grup kelas masing-masing agar mempermudah siswa dalam pengisiannya, dengan skor 1-4, sehingga diperoleh rentang skor ideal 31 - 124. Setelah data diperoleh, diskor, dan dianalisis dengan bantuan software Microsoft Excel 2013, diperoleh nilai minimum $=71$; nilai maksimum $=124$; rata-rata (mean) $=95,81$; standar deviasi $=12,96$. Hasil penelitian tersebut dideskripsikan dengan empat kategori,yang hasil nya dapat dilihat pada tabel 2 berikut. 
ISSN 2356-3397 (Print) | ISSN 2597-4505 (Online)

Tabel 2. Hasil Keseluruhan Persepsi Siswa Keseluruhan

\begin{tabular}{|c|c|c|c|c|c|c|}
\hline No & \multicolumn{3}{|c|}{ Interval } & Kategori & Frekuensi & $\%$ \\
\hline 1 & & $x>$ & 108,77 & sangat baik & 15 & $17 \%$ \\
\hline 2 & 95,81 & $<x<$ & 108,77 & Baik & 19 & $21 \%$ \\
\hline 3 & 82,85 & $<x<$ & 95,81 & cukup baik & 45 & $50 \%$ \\
\hline 4 & & $x<$ & 82,85 & kurang baik & 11 & $12 \%$ \\
\hline
\end{tabular}

Dari tabel diatas dapat disimpulkan bahwa tes hasil keseluruhan persepsi siswa kelas VIII terhadap pembelajaran aktivitas akuatik di SMP islam al-falah Bantargebang sebagian besar dalam kategori "Cukup Baik" dengan persentase 50\%. Berdasarkan hasil penelitian tersebut diketahui persepsi siswa kelas VIII terhadap pembelajaran aktivitas akuatik di SMP Islam Al-falah Bantargebang yang menyatakan pada kategori "sangat baik" dengan persentase 17\%, pada kategori "baik" dengan persentase 19\%, pada kategori "cukup baik" dengan persentase 50\%,pada kategori "kurang baik" dengan persentase $12 \%$. Diagram hasil keseluruhan persepsi dapat dilihat pada gambar 1 berikut.

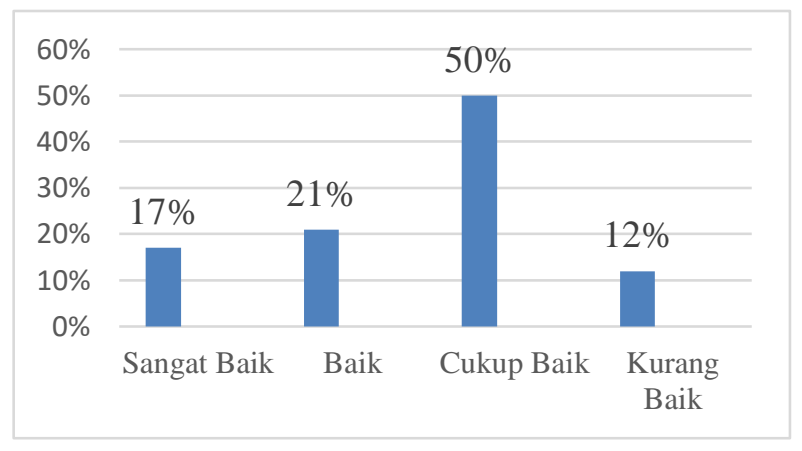

Gambar. 1. Diagram Hasil Keseluruhan Persepsi Siswa

\section{Faktor Internal}

Faktor Internal merupakan suatu pengaruh yang bersumber dari dalam diri sendiri meliputi, proses belajar, motivasi dan kepribadian. persepsi siswa Kelas VIII terhadap pembelajaran aktivitas akuatik di SMP Islam Al-falah Bantargebang berdasarkan faktor internal diukur dengan angket yang berjumlah 14 butir pernyataan dengan skor 1-4, sehingga diperoleh rentang skor ideal 14-56. Setelah data diperoleh, diskor, dan dianalisis dengan bantuan software Microsoft Excel 2013, diperoleh nilai minimum $=26$; nilai maksimum $=56$; rata- rata $($ mean $)=42,43$; standar deviasi $=6,38$. Hasil penelitian faktor internal secara keseluruhan tersebut dideskripsikan dengan empat kategori yang hasilnya dapat dilihat pada tabel 3.

Tabel 3. Hasil Persepsi Siswa Kelas VIII dari Faktor Internal

\begin{tabular}{|c|c|c|c|c|c|c|}
\hline No & \multicolumn{3}{|c|}{ Interval } & Kategori & Frekuensi & $\%$ \\
\hline 1 & & $x>$ & 48,82 & sangat baik & 13 & $14 \%$ \\
\hline 2 & 42,43 & $<X<$ & 48,82 & baik & 25 & $28 \%$ \\
\hline 3 & 36,05 & $<x<$ & 42,43 & cukup baik & 41 & $46 \%$ \\
\hline 4 & & $x<$ & 36,05 & kurang baik & 11 & $12 \%$ \\
\hline
\end{tabular}


Dari tabel diatas dapat disimpulkan bahwa tes hasil internal persepsi siswa kelas VIII terhadap pembelajaran aktivitas akuatik di SMP Islam Al-falah Bantargebang sebagian besar dalam kategori "Cukup Baik" dengan persentase sebesar 46\%. Diagram persepsi siswa terhadap pembelajaran aktivitas aquatik dari faktor internal tersaji pada gambar 2.

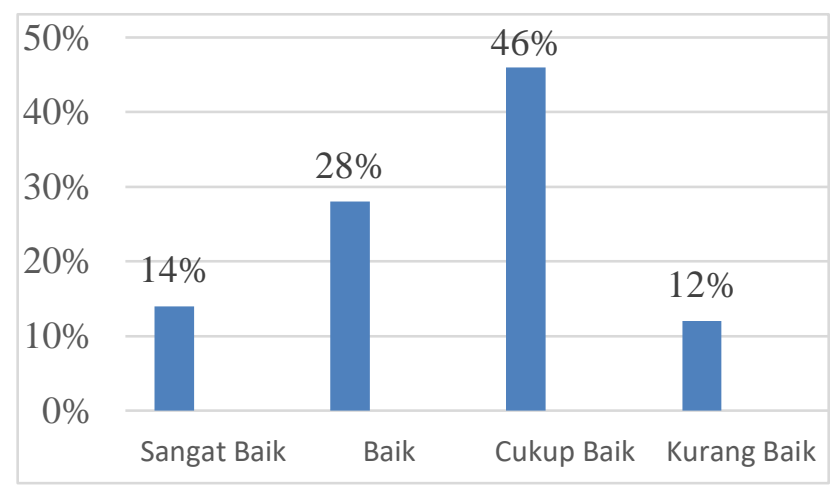

Gambar 2. Diagram Persepsi Siswa dari Faktor Internal

Dari hasil diagram internal penelitian tersebut diketahui Persepsi Siswa Kelas VIII Terhadap Pembelajaran Aktivitas Akuatik di SMP Islam Al-falah Bantargebang yang menyatakan pada kategori "sangat baik" dengan persentase $14 \%$, pada kategori "baik" dengan persentase $28 \%$, pada kategori "cukup baik" dengan persentase $46 \%$, pada kategori "kurang baik" dengan persentase $12 \%$.

\section{Faktor Eksternal}

Faktor eksternal merupakan suatu pengaruh atau pandangan yang bersumber dari lingkungan sekitar meliputi, intensitas, ukuran, keberlawanan, pengulangan, gerakan, dan hal-hal yang baru. Persepsi Siswa Kelas VIII Terhadap Pembelajaran Aktivitas Akuatik di SMP Islam Al-falah Bantargebang secara keseluruhan diukur dengan angket yang berjumlah 16 butir pernyataan dengan skor $1-4$, sehingga diperoleh rentang skor ideal 16-64. Setelah data diperoleh, diskor, dan dianalisis dengan bantuan software Microsoft Excel 2013, diperoleh nilai minimum = 38; nilai maksimum = 64; rata$\operatorname{rata}($ mean $)=50,42$; standar deviasi $=6,66$. Hasil penelitian faktor eksternal secara keseluruhan tersebut dideskripsikan dengan empat kategori yang hasilnya dapat dilihat pada tabel 4.

Tabel 4. Hasil Persepsi Siswa Kelas VIII dari Faktor Eksternal

\begin{tabular}{|c|c|c|c|c|c|c|}
\hline No & \multicolumn{3}{|c|}{ Interval } & Kategori & Frekuensi & $\%$ \\
\hline 1 & & $x>$ & 57,08 & sangat baik & 15 & $17 \%$ \\
\hline 2 & 50,42 & $<x<$ & 57,08 & baik & 19 & $21 \%$ \\
\hline 3 & 43,76 & $<x<$ & 50,42 & cukup baik & 48 & $53 \%$ \\
\hline 4 & & $x<$ & 43,76 & kurang baik & 8 & $9 \%$ \\
\hline
\end{tabular}


Dari tabel diatas dapat disimpulkan bahwa tes hasil faktor ekternal persepsi siswa kelas VIII terhadap pembelajaran aktivitas akuatik di SMP islam al-falah Bantargebang sebagian besar dalam kategori "Cukup Baik" dengan persentase 53\%. Diagram persepsi siswa terhadap pembelajaran aktivitas aquatik dari faktor eksternal tersaji pada gambar 3.

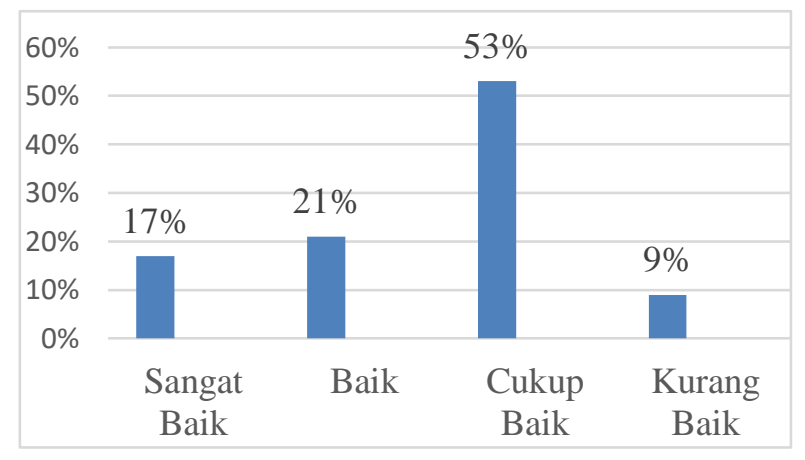

\section{Gambar 2. Diagram Persepsi Siswa dari Faktor Eksternal}

Dari hasil diagram faktor eksternal penelitian tersebut diketahui Persepsi Siswa Kelas VIII Terhadap Pembelajaran Aktivitas Akuatik di SMP Islam Alfalah Bnatatrrgebang yang menyatakan pada kategori "sangat baik" dengan persentase 17\%, pada kategori "baik" dengan persentase $21 \%$, pada kategori "cukup baik" dengan persentase $53 \%$, pada kategori "kurang baik" dengan persentase $9 \%$.

\section{Pembahasan}

Dengan kondisi persepsi siswa pada pembelajaran aktivitas akuatik di SMP Islam Al-Falah Bantargebang Bekasi yang berada pada kategori cukup baik (45 orang atau sekitar $50 \%$ ) ini menjadi perhatian khusus bagi guru olahraga SMP Islam Al-Falah Bantargebang. Karena persepsi siswa tersebut perlu ditingkatkan kembali dan menjadi bahan evaluasi untuk guru olahraga dalam meningkatkan kualitas pembelajaran. Persepsi yang terjadi pada diri individu, tidak berlangsung begitu saja namun melalui proses, ada beberapa tahapan proses yang terjadinya persepsi menurut (Walgito, 2010:101), yaitu adanya sebuah objek yang di persepsi, melalui alat indera atau reseptor, adanya perhatian. Dalam keadaan itu menunjukan bahwa individu tidak hanya di kenai satu stimulus saja, melainkan beberapa macam stimulus yang di timbulkan oleh suatu keadaan sekitar. Tetapi tidak semua stimulus akan di respon oleh individu. Respon akan diberikan oleh individu terhadap stimulus yang menarik perhatian individu. Selain itu proses terjadinya persepsi di pengaruhi beberapa faktor menurut (Adhitama, 2016) yaitu faktor internal dan eksternal, faktor internal meliputi proses belajar, kepribadian, dan motivasi sedangkan faktor eksternal meliputi intensitas, ukuran, keberlawanan, pengulangan gerakan, hal-hal yang baru, dan informasi yang di peroleh. Faktor yang paling baik yaitu faktor eksternal berada pada kategori cukup baik dengan persentase $53 \%$. Karena faktor eksternal merupakan perhatian yang bersumber dari luar diri seseorang, yang dapat menimbulkan banyak pengaruh bagi seseorang tersebut (Abidin \& Prihanto, 2016).

Dan faktor yang paling kurang bersumber dari faktor internal, berada pada kategori cukup baik dengan persentase $46 \%$. Karena faktor internal merupakan faktor perhatian yang berasal dari dalam diri seseorang, ini menyebabkan faktor internal seseorang mudah dipengaruhi olah faktor eksternal jika faktor internal diri seseorang tidak begitu kuat (Firmansyah, 2016). Pengenalan pembelajaran aktivitas akuatik adalah suatu 


\section{Volume 8, Nomor 1, April 2021 \\ ISSN 2356-3397 (Print) | ISSN 2597-4505 (Online)}

bentuk pembelajaran latihan dasar sebelum siswa di ajarkan gerakan masing-masing gaya renang. Tujuan dari pembelajaran aktivitas akuatik ini di harapkan untuk membentuk sikap, keterampilan mengapung dan meluncur dengan sejajar pada permukaan air (Susanto, 2013:4). Pengenalan pembelajaran aktivitas akuatik dapat dibagi menjadi dalam berbagai beberapa pokok kegiatan dan di sesuaikan dengan tujuannya dalam pembelajaran aktivitas akuatik dibagi menjadi empat bagian yaitu pengenalan air, permainan air, keselamatan di air, dan renang (Mikanda, 2017:20). Pengenalan pembelajaran aktivitas akuatik sangat tepat diberikan kepada siswa yang belum pernah sama sekali mengikuti belajar renang. di karenakan kemungkinan masih ada siswa yang takut kedalam kolam, maka dari itu guru-guru pendidikan jasmani hendaknya memahami pengenalan pembelajaran aktivitas akuatik.

\section{SIMPULAN DAN SARAN Simpulan}

Berdasarkan data hasil penelitian dapat diketahui bahwa persepsi siswa kelas VIII terhadap Pembelajaran Aktivitas Akuatik di SMP Islam Al-falah Bantargebang merupakan kategori sangat baik dengan jumlah sebanyak 15 siswa (17\%), kategori baik dengan jumlah sebanyak 19 siswa (21\%), kategori cukup baik dengan jumlah 45 siswa $(50 \%)$, kategori kurang baik dengan jumlah 11 siswa (12\%). Dapat dilihat dari perhitungan tersebut bahwa persepsi siswa kelas VIII terhadap pembelajaran Aktivitas Akuatik di SMP Islam Al-falah Bantargebang dalam kategori cukup baik dengan persentase $50 \%$ sejumlah 45 siswa.

\section{Saran}

Bedasarkan penelitian tersebut terdapat saran yang akan disampaikan oleh peneliti yaitu :

1. Bagi siswa yang masih mempunyai persepsi yang rendah terhadap penilaian pembelajaran aktivitas akuatik diharapkan dapat membuka wawasannya, agar dapat memberikan suatu pandangan pribadi yang bersifat untuk membangun proses pembelajaran aktivitas akuatik dikemudian hari. Sampaikan apa yang dilihat dan dialami sebaik mungkin tidak harus menambah-nambahkannya karena penilain dari persepsi siswa ini sebagi acuan guru untuk meningkatkan kualitas dalam proses pembelajaran kedepannya.

2. Bagi guru penjas sebelum mengajar perlu memperhatikan tanggapan siswa terhadap pembelajaran aktivitas akuatik yang dilakukan. Jika telah diketahui seberapa besar tanggapan siswa terhadap pembelajaran yang di lakukan, maka guru akan lebih mudah ke arah mana materi maupun metode-metode mengajar yang dilakukan sehingga pembelajaran aktivitas akuatik dapat lebih bermanfaat.

3. Telah diketahui indikator eksternal lebih dominan memberi pengaruh terhadap pembelajaran aktivitas akuatik dari pada faktor internal. Maka dari itu guru penjas harus memotivasi lagi kepada siswanya agar minat dan perhatian terhadap pembelajaran aktivitas akuatik lebih baik lagi.

4. Bagi peneliti selanjutnya hendaknya melakukan penelitian dengan sampel dan populasi yang lebih luas, sehingga tingkat persepsi siswa tidak hanya pada pembelajaran aktivitas akuatik saja tetapi seluruh pembelajaran pendidikan jasmani agar dapat teridentifikasi lebih luas lagi 


\section{DAFTAR PUSTAKA}

Abidin, M. F., \& Prihanto, J. B. (2016). Perbandingan Tingkat Kebugaran Jasmani Antara Siswa Yang Mengikuti Ekstrakurikuler Futsal di SMAN 1 Taman Sidoarjo Dengan SMA Khadijah Surabaya. Jurnal Pendidikan Olahraga Dan Kesehatan, 4(3), 617622.

Adhitama, S. W. (2016). Persepsi Siswa Kelas VIII Terhadap Pembelajaran Aktivitas Air di SMP Negeri 2 Klaten. Pendidikan Jasmani Kesehtan Dan Rekreasi, 1(2), 1-7.

Arikunto, S. (2014). Prosedur Penelitian (cetakan kelima belas). Jakarta: PT. Rineka Cipta.

Febrianto, M., \& Priambodo, A. (2019). Perbedaan Persepsi Siswa Smp Negeri Dengan Siswa Smp Swasta Terhadap Mata Pelajaran Pendidikan Jasmani Olahraga Dan Kesehatan Di Kecamatan Lamongan. Jurnal Pendidikan Jasmani, 07(1), 19-25.

Firmansyah. (2016). Penerapan Teori Pembelajaran Kognitif dalam Pembelajaran Pendidikan Jasmani dan Kesehatan. Jurnal Pendidikan Olahraga, 5(2), 154-164.

Gani, Ruslan abdul, A. Sukur, S. N. (2019). Peningkatan Kemampuan Renang Gaya Kupu-Kupu. Jp.Jok (Jurnal Pendidikan Jasmani Olahraga Dan Kesehatan), 18(2), 107-113.

Gani, R. A., Tangkudung, J., \& Dlis, F. (2019). Materi Dan Model Latihan Renang Gaya Kupu-Kupu Berbasis Drill (U. Nugroho (ed.); Pertama). CV. Sarunu Untung.

Hendri,Gus.Aziz, I. (2020). Motivasi siswa dalam proses pembelajaran pendidikan jasmani olahraga kesehatan 1,2. Patriot, 2, 171-181.

Jayamala, A. K., R Latha, B. L. Preethi, Nirmala N, K Tamilselvan, K. P. (2018). Peningkatan Hasil Belajar Passing Bawah Bola Voli Dengan Pembelajaran Kooperatif. International Journal of Physiology, 6(1), 2018.

Khodari, R. (2017). Evaluasi Program Pendidikan Kelas Khusus Olahraga Sekolah Menengah Atas Negeri 1 Sewon Bantul Yogyakarta. Multilateral Jurnal Pendidikan Jasmani Dan Olahraga, 15(2), 124-132. https://doi.org/10.20527/multilateral.v15i2.2740

Mashud. (2014). KELAS III SEKOLAH DASAR Mashud Konsepsi pembelajaran adalah sebuah usaha untuk membelajarkan, supaya belajar menjadi lebih mudah bagi peserta didik ( Dwiyogo , Pembelajaran dalam kontek ini adalah pembelajaran Pendidikan Jasmani Olahraga dan dimana pembe. Jurnal Pendidikan Jasmani Dan Olahraga, 13(1), 1-19.

Mikanda, R. (2017). Buku Pintar Renang (F. Sugih (ed.); Pertama). Anugrah.

Prastyo, G. M., Kurniawan, F., \& Resita, C. (2020). Pengaruh Model Pembelajaran Blended Learning Dalam Kebugaran Jasmani Terhadap Motivasi Belajar Siswa Sekolah Ma Nurul Huda. Jurnal Literasi Olahrag, 1(August), 60-65.

Ruspiandi, Y. (2016). Persepsi Siswa Sma N 1 Parigi Pangandaran Terhadap Pembelajaran Renang. Pendidikan Jasmani Olahraga, 1-7.

Sandhi, E. W., \& Hartanto, T. (2018). Persepsi Siswa Terhadap Hasil Belajar Aktivitas Aquatik di SMPN 1 Lemahabang. J-Speed, 1-2, 96-98.

Septiana, A. (2016). Hubungan Gaya Belajar dan Persepsi Siswa Tentang Metode Mengajar Guru Terhadap Prestasi Belajar Matematika Pada Siswa-Siswi Kelas XI SMA Negeri 1 Sangatta Utara Kutai Timur. EJournal Psikologi, 4(2), 165-176.

Sofiarini, A. M. (2016). Hubungan Antara Pembelajaran Penjas Dengan Perilaku Sosial 
Siswa (Studi Deskriptif di SMA Negeri 10 Kota Bandung). Jurnal Pendidikan Jasmani Dan Olahraga, 1(1), 68. https://doi.org/10.17509/jpjo.v1i1.3665

Sugiyono. (2018). Metode Penelitian Kuantitatif, Kualitatif, Dan R\&D (ke-26). Alfabeta, cV.

Sukmawati, D., \& Hartoto, S. (2015). Penerapan Pemebelajaran Renang Gaya Bebas Terhadap Hasil Belajar Renang Gaya Bebas. Jurnal Pendidikan Olahraga Dan Kesehatan, 03(2), 366-370.

Susanto, E. (2013). Media Audio Visual Akuatik Untuk Meningkatkan Kualitas Pembelajaran. Jurnal Penelitian Pendidikan, 369(1), 1689-1699. https://doi.org/10.1017/CBO9781107415324.004

Walgito, B. (2010). Pengantar Piskologi Umum (A. Offest (ed.); Revisi).

Wibowo, H., \& Gani, R. A. (2018). Pendidikan Jasmani Materi Ajar Passing Bawah Dalam Permainan Bolavoli Pada Siswa Kelas VII SMP Negeri 2 Majalaya. Jurnal Speed, 1(1), 45-50. 